\title{
Duration effect of fresh semen kept in vitro on sheep conception rate
}

\author{
Müzeyyen Kutluca Korkmaz ${ }^{1}$, Ebru Emsen ${ }^{2,4}$, Afşin Köker ${ }^{3}$, Mesih Kocamüftüoğlu ${ }^{3}$ \\ ${ }^{1}$ Ispir Hamza Polat Vocational School, Ataturk University, 25900 Ispir, Erzurum, Turkey. \\ ${ }^{2}$ Department of Animal Science, Faculty of Agriculture, Ataturk University, 25240 Erzurum, Turkey \\ ${ }^{3}$ Department of Obstetrics and Gynecology, Faculty of Veterinary Sciences, Mehmet Akif Ersoy University, \\ 15030 Burdur, Turkey.
}

\begin{abstract}
Yearling Akkaraman ewes $(\mathrm{n}=140)$ were apportioned into two groups and inseminated with fresh semen collected from Suffolk and Dorper rams. Bilateral intrauterine insemination $\left(\begin{array}{llll}100 & \text { x } & 106\end{array}\right.$ spermatozoa in $0.25 \mathrm{ml}$ ) was performed with the aid of laparoscope. Fixed time insemination was carried out 48-50 $\mathrm{h}$ after controlled intravaginal drug release (CIDR) removal with the aid of estrus detection using vasectomized rams. Uterine tone at the time of insemination was scored (1-3), the highest pregnancy rate achieved for ewes with score $3(67 \%)$, followed by 59 and $47 \%$ for scores 2 and 1, respectively. General decrease in pregnancy rates were observed with increased duration of stored fresh semen over the insemination period (Fall from 73 to $57 \%$ over $120 \mathrm{~min}$ storage). However, a slight increase in conception rate was observed at the time of AI with the semen kept in vitro for a longer period (90-120 m) which might be the most appropriate time relative to ovulation.
\end{abstract}

Keywords: aged semen, Dorper, fat tailed sheep, fresh semen, Suffolk.

\section{Introduction}

Akkaraman is the most common endemic fat tailed sheep breed in Turkey accounting for $37 \%$ of the total sheep population. The breed is well known for its resistance to diseases and parasites as well as converting poor quality forage to valuable animal sourced products. The breeds' meat/carcass quality and prolificacy characteristics however are low, usually producing a single drop. Improving the carcass traits have always been one of the more important breeding goals for the Akkaraman breed in the Turkish sheep industry creating a large demand for improved terminal sire crossbreeding programs. The limiting factor for an effective mating between fat tailed Akkaraman ewes and rams from thin tailed exotic meat breeds such as Dorper and Suffolk, is the need for assistance in lifting up the fat tail of the ewe for the inexperienced exotic rams to better perform. As this process is not often practical and as unassisted copulation is mostly ineffective, artificial insemination (AI) is often essential.

AI is necessary not only for overcoming mating problems due to the fat tail issues but also a valuable technique to improve reproductive performance and introduce new genetics. Laparoscopic AI (LAI) has evolved as one of the most viable techniques for depositing semen in the uterus of the sheep and fertility may reach up to $70 \%$ (McKelvey, 1985; Hill et al., 1998).

For artificial insemination (AI) in sheep, intrauterine semen deposition is a necessity for obtaining high lambing rates. Conception rates after intrauterine insemination are acceptable not only with freshly collected semen both also with frozen then thawed semen that has been subjected to minimal handling. Pregnancy rates of fat tailed ewes conducted from several studies ranged from $30-75 \%$ with fresh and frozen thawed semen (Emsen et al., 2008, 2011; Atsan et al., 2009). AI is limited by the short storage time (8 h) required for fresh semen. Fresh semen should be used immediately after it is collected, as the motility and viability of the spermatozoa under these conditions is quickly reduced, due to the increase in the concentration of lactic acid in the ejaculate (Vivanco, 1988). It was indicated that the adverse effects of sperm aging are likely mediated by membrane changes associated with increased lipid peroxidation, with the effect of reducing numbers of viable sperm available to form a sperm reservoir in Boar semen (Kumaresan et al., 2009; Am-in et al., 2011). Uterine tone has also been scored during the laparoscopic artificial insemination (LAI) in this study. Gimenez-Diaz et al. (2012) reported that uterine tone, a measure of quality of heat, was significantly related to conception rates when it is measured at the time of intrauterine insemination. In a large scale epidemiological study, Anel et al. (2005) observed that the male factor significantly influenced fertility. Salamon and Maxwell (1995) proposed that ram differences in fertility could be both genetic and environmental, whereas ejaculate differences are probably due to nutrition, management and previous frequency of ejaculation (concentration of spermatozoa).

Limited information based on ram semen aging led us to conduct the present study. We hypothesized that there might be an adverse effect of increased sperm age on conception rates. Therefore, the objective of the experiment described here was to determine the effect of ram genotype, uterine tone and holding time of fresh semen on pregnancy rates in fat tailed yearling Akkaraman ewes. 


\section{Materials and Methods}

This study was approved by the animal ethics committee of the Ataturk University and was carried out on a commercial farm in Burdur, southern Turkey in April. A total of 140 Akkaraman fat tailed yearling ewes at the commercial sheep enterprise were used for the present study. The ewes had a moderate body condition score (average 2.5-3.0). Production is based on a semiintensive system and the Akkaraman is a seasonal breed. The ewes were treated for 12 days with controlled internal drug release devices (CIDR) containing $300 \mathrm{mg}$ progesterone (Eazi-Breed CIDR, Inter Ag, Hamilton, New Zealand). At pessary removal all ewes were injected intramuscularly with 500 UI of equine chorionic gonadotrophin (eCG). Estrus detection was performed with the aid of two vasectomized rams equipped with a canvas apron three times a day (6:00 a.m., 2:00 p.m. and 9:00 p.m.) for 3 days after pessary removal and insemination took place $48-50 \mathrm{~h}$ after CIDR removal. Time of semen collection and the subsequent insemination was recorded to ensure that the protocol for the aging process was adhered to as per the allocated groups.

Ewes were randomly allocated to two groups according to the breed of rams; 93 ewes were inseminated with semen from a Suffolk ram and 47 ewes with semen from a Dorper ram. After collection of semen from only one ram per breed, each ejaculate was evaluated for volume and motility. Ejaculates of more than $0.5 \mathrm{ml}$ and good motility $(>70 \%)$ were used for pooling procedure. Semen was extended at $35^{\circ} \mathrm{C}$ in OviPro ${ }^{\circledR}$ (Minitüb, Tiefenbach, Germany) and maintained at $30^{\circ} \mathrm{C}$ in a water bath. Ewes inseminated with freshly diluted semen containing $100 \times 106$ motile spermatozoa per $0.25 \mathrm{ml}$. Laparoscopic artificial insemination (LAI) was performed by a single experienced LAI operator 48-50 h. after CIDR withdraw. All ewes were fasted and had no access to water for $18 \mathrm{~h}$ before laparoscopy. Ewes received i.v. injection of an anesthetic cocktail containing $2 \mathrm{cc}$
Ketasol (Indus Pharma, Karachi, Pakistan) $+0.04 \mathrm{cc}$ Romphun (Bayer) before insemination and were placed in laparoscopic cradles and kept in dorsal recumbent position while 2 trocars (10 and $5 \mathrm{~mm}$ ) were inserted at $5 \mathrm{~cm}$ on either side of the midline to allow for the introduction of a laparoscope (Richard Wolf $\mathrm{GmbH}$, Knittlingen, Germany) and an insemination pipette (Aspic UA 091, IMV, L'Aigle, France), respectively. Compressed air was insufflated into the abdominal cavity immediately before insemination. Semen was then deposited into the lumen of the mid portion of both the uterine horns. At the time of laparoscopic AI, uterine tone was scored as no tone (1), moderate tone (2) or intense tone (3). Uterine tone is determined as a measure of quality of heat conducive to the implantation of the zygote. All ewes were scanned trans abdominally by using a real-time ultrasound scanner equipped with a $5 \mathrm{MHz}$ linear-array transducer (Pie Medical, 100 Falco. Vet) at day 55 post insemination.

To determine the effect of ram breed, semen aging and uterine tone on conception rate, Kruskal-Wallis and Mann-Whitney U tests were applied. SPSS v.20 software was used under license to Ondokuz Mayis University. Binary logistic regression was used to determine the effect of semen aging on conception rate. Chi-Square dependency test was used to determine the dependency of breed, semen aging and uterine tone on conception rate.

\section{Results}

The conception rate obtained in this study using fresh diluted semen did not differ significantly for the ewes inseminated with semen from different breeds of ram. The conception rates related to the uterine tone score at the time of intrauterine insemination were not statistically different. Ewes with a uterine tone score of 3 had an average $67 \%$ conception rate while scores 1 and 2 resulted with 47 and $59 \%$, respectively. Overall conception rate dropped by $16 \%$ over a 90 min fresh semen ageing period (Table 1).

Table 1. Effect of ram breed, uterine tone and semen aging on conception rate of fat tailed ewes.

\begin{tabular}{|c|c|c|c|}
\hline Breed & $\mathrm{n}$ & Conception rate $(\%) X_{ \pm} \bar{X}$ & $\mathrm{X} 2$ \\
\hline Suffolk & 93 & $0.59 \pm 0.05$ & 3.108 \\
\hline Dorper & 47 & $0.57 \pm 0.07$ & 1.043 \\
\hline Sig. & & 0.848 & \\
\hline Dependency (\%) & & 1.8 & \\
\hline Semen aging $(\min )$ & & $\bar{X} \pm S \bar{X}$ & \\
\hline $0-29$ & 33 & $0.73 \pm 0.08^{\mathrm{a}}$ & 6.818 \\
\hline $30-59$ & 41 & $0.66 \pm 0.07^{\mathrm{a}}$ & 4.122 \\
\hline $60-89$ & 35 & $0.39 \pm 0.08^{\mathrm{b}}$ & 1.400 \\
\hline $90-119$ & 24 & $0.57 \pm 0.09^{\mathrm{b}}$ & 0.167 \\
\hline Sig. & & 0.024 & \\
\hline Dependency $(\%)$ & & 25 & \\
\hline Uterus Tone & & $\mathrm{X}^{-} \pm S \bar{X}$ & \\
\hline 1 & 43 & $0.47 \pm 0.07$ & 5.233 \\
\hline 2 & 37 & $0.59 \pm 0.08$ & 1.324 \\
\hline 3 & 15 & $0.67 \pm 0.13$ & 1.667 \\
\hline Sig. & & 0.744 & \\
\hline Dependency (\%) & & 6.2 & \\
\hline
\end{tabular}


Binary logistic regression was used to determine the effect of semen aging on conception rate, where correct classification rate was assessed at $83 \%$. The odds ratio determined that with every $30 \mathrm{~min}$ intervals of semen ageing protocols used in the present study in insemination, the likelihood of reduced conception increased by 47, 105, 302 and 806\% respectively.

The same regression analysis method was also used to determine the effect of uterine tone on conception rates and the model showed no significance between the two factors. Correct classification rate was assessed at $64 \%$ for this analysis. The dependency of semen ageing to successful conception rate were found to be significant $(25 \%)$.

\section{Discussion}

Results of the present study revealed that decrease in sperm function was associated with an increase in holding time which was in agreement with previous studies reported in cattle (O'Flahert et al., 1999) and buffalo (Kumaresan et al., 2006). Variations in the fertility of rams have been reported after cervical inseminations with fresh semen (Paulenz et al., 2002; Anel et al., 2005) and after laparoscopic inseminations with frozen semen (Eppleston et al., 1986, 1991; Maxwell, 1986; Eppleston and Maxwell, 1995). Our current study indicates that fresh diluted semen form Suffolk and Doper rams resulted with 59 and 57\% conception rates, respectively (Table 1). Although seasonality is less marked in males than in females, changes in testicular volume, hormonal profiles, sexual behaviour and semen quality that affect the reproductive performance of rams have been reported (Casao et al., 2010). Olah (2010) reported that the largest scrotal circumference (SC) was measured in spring for the Suffolk $(35.8 \mathrm{~cm})$ while for the Dorper breed, the largest values measured in the summer. Olah (2010) also indicated that in all seasons, a medium positive significant correlation was found between body weight and scrotal circumference. Suffolk ram $(98 \mathrm{~kg})$ used in this study was heavier than Dorper ram $(92 \mathrm{~kg})$, this may have been the reason for the slightly better performance of the Suffolk semen.

In our study, the uterine tone at the time of laparoscopic insemination was found not to have a linear (positive) association with conception rates, which was contrary to the findings of Gimenez-Diaz et al. (2012). Our results are in agreement with Pervage et al. (2009) who reported the that number of live spermatozoa and the sperm motility decreased with increasing age of semen. It was hypothesized that incubating ram sperm in the manner presented here at $30^{\circ} \mathrm{C}$ for times greater than $60 \mathrm{~min}$, may have a detrimental effect and result in a decline $(46 \%)$ in the overall conception rate.

In conclusion, using fresh diluted ram semen stored at $30^{\circ} \mathrm{C}$ within $60 \mathrm{~min}$ of collection gave acceptable results when used for intrauterine insemination. In the current study, we focused on duration of semen storage and the uterine tone of the ewe at the time of insemination. Pregnancy rate decreased when ewes were inseminated with aged semen kept in vitro for more than $60 \mathrm{~min}$. Further studies related to semen ageing and uterus tone are needed.

\section{Acknowledgments}

Authors acknowledge Dr Ileana Wenger for linguistic revision.

\section{References}

Am-in N, Tantasuparuk W, Manjarin R, Kirkwood RN. 2011. Effect of site of sperm deposition on fertility when sows are inseminated with aged semen. J Swine Health Prod, 19:295-297.

Anel L, Kaabi M, Abroug B, Alvarez M, Anel E, Boixo JC, De la Fuente LF, De Paz P. 2005. Factors influencing the success of vaginal and laparoscopic artificial insemination in churra ewes: a field assay. Theriogenology, 63:1235-1247.

Atsan T, Emsen E, Yaprak M, Diaz CAG, Koycegiz F, Kutluca M. 2009. Comparative economic returns from artificial insemination and natural service in Purebred Fat Tailed and Crossbred Romanov flock. $J$ Anim Vet Adv, 8:80-84.

Casao A, Cebrian I, Asumpcao ME, Perez-Pe R, Abecia JA, Forcada F, CebrianPerez JA, MuinoBlanco T. 2010. Seasonal variations of melatonin in ram seminal plasma are correlated to those of testosterone and antioxidant enzymes. Reprod Bio Endocrinol, 8:59. doi: 10.1186/1477-7827-8-59.

Emsen E, Gimenez Diaz CA, Yaprak M, Koycegiz F, Kutluca M, Aslan FA. 2008. Factors affecting the reproductive performance of fat-tailed ewes inseminated with laparoscopy in the late breeding season. Anim Reprod, 5:30-33.

Emsen E, Giménez Diaz C, Kutuca M, Koycegiz F. 2011. Reproductive response of ewes synchronized with different lengths of MGA treatments in intrauterine insemination program. Anim Reprod Sci, 126:57-60.

Eppleston J, Maxwell WMC, Battye KM, Roberts EM. 1986. Effect of thawed motility and intrauterine motility of motile sperm on fertility of ewes. Proc Aust Soc Reprod Biol, 18:19. (abstract).

Eppleston J, Evans G, Roberts EM. 1991. Effect of time of PMSG and GnRH on the time of ovulation, LH secretion and reproductive performance after intrauterine insemination with frozen ram semen. Anim Reprod Sci, 26: 227-237.

Eppleston J, Maxwell WMC.1995. Sources of variation in the reproductive performance of ewes inseminated with frozen-thawed ram semen by laparoscopy. Theriogenology, 43:777-788.

Gimenez-Diaz C, Emsen B, Emsen E, Kutluca M, Koycegiz F. 2012. Improved reproductive response of sheep in intrauterine insemination program with the use of royal jelly. Afr J Biol, 11:12518-12521.

Hill JR, Thompson JA, Perkins N. 1998. Factors affecting pregnancy rates following laparoscopic insemination of 28,447 Merino ewes under commercial 
conditions: a survey. Theriogenology, 49:697-709.

Kumaresan A, Ansari MR, Garg A, Kataria M. 2006. Effect of oviductal proteins on sperm functions and lipid peroxidation levels during cryopreservation in buffaloes. Anim Reprod Sci, 93:246-257.

Kumaresan A, Kadirvel G, Bujarbarbaruah KM, Bardoloi RK, Das A, Kumar S, Naskar S. 2009. Preservation of boar semen at $18^{\circ} \mathrm{C}$ induced lipid peroxidation and apoptosis like changes in spermatozoa. Anim Reprod Sci, 110:162-171.

Maxwell WMC. 1986. Artificial insemination of ewes with frozen-thawed semen at a synchronized oestrus. 2 . Effect of dose of spermatozoa and site of intrauterine insemination on fertility. Anim Reprod Sci, 10:309-316.

McKelvey WAC, Robinson JJ, Aitken RP. 1985. The evaluation of a laparoscopic insemination technique in ewes. Theriogenology, 24:519-535.

O'Flahert CM, Beorlegui NB, Beconi M. 1999. Reactive oxygen species requirements for bovine sperm capacitation and acrosome reaction. Theriogenology, 52:289-301.
Olah J. 2010. Factors influencing the quality of sheep semen. Debrecen, Hungary: Debrecen University. PhD Thesis.

Paulenz H, Adnoy T, Fossen OH, Soderquist L, Berg KA. 2002. Effect of deposition site and sperm number on the fertility of sheep inseminated with liquid semen. Vet Rec, 150:299-302.

Pervage S, Hassan MR, Ershaduzzaman M, Khandoker M. 2009. Preservation of liquid semen and artificial insemination in native sheep. $J$ Bangladesh Agric Univ, 7:305-308.

Salamon S, Maxwell WMC. 1995. Frozen storage of ram semen I. Processing, freezing, thawing and fertility after cervical insemination. Anim Reprod Sci, 37:185249.

Vivanco MHW. 1998. Inseminación artificial en ovinos. In: Memorias del Seminario Internacional: Aplicación de Técnicas Biotecnológicas en la Reproducción de Ovinos y Caprinos, 1998, Chapingo, México. Chapingo, Mexico: Universidad Autónoma Chapingo. pp. 135-194. 